Acta vet. scand. $1973,14,263-271$.

From the Department of Clinical Biochemistry and the Department of Pathology, Royal Veterinary College, Stockholm, the Department of Pathology, National Veterinary Institute, Stockholm, and the Department of Animal Husbandry, Agricultural College, Uppsala, Sweden.

\title{
HEMATOLOGICAL AND BLOOD CHEMICAL DATA IN PIGS FED ON FINE, MEDIUM AND COARSE GROUND DRY GRAIN
}

\author{
By \\ Bo Crabo, Nils-Erik Björklund and Allan Simonsson
}

CRABO, BO, NILS-ERIK BJÖRKLUND and ALLAN SIMONSSON: Hematological and blood chemical data in pigs fed on fine, medium and coarse ground dry grain. Acta vet. scand. 1973, 14, 263-271. Blood was collected the day before slaughter from pigs fed fine, medium or coarse ground grain and examined in accordance with Tables $1-3$. Of the 15 pigs (group 1) on the finest meal all except one developed parakeratotic or erosive changes (Figs. $1-5$ ) in the pars oesophagea of the stomach. In group 2 (medium ground) the corresponding number was seven out of 18 . No pathological alterations could be detected in the stomach of the pigs on coarse grain.

Statistically significant or almost significant differences were obtained between the groups for hemoglobin, hematocrit, number of erythrocytes, urea-N and pepsinogen. $A$ much wider range was observed in the $\gamma$-globulins of the group on fine grain than in the other two groups. The differences in proteins were, however, not significant. To see whether the observed differences between the groups were related to the gastric pathological alterations or to the feed, a comparison was made between pigs with and without pathological changes (Table 3). There were still significant, though smaller, differences in the hemoglobin and hematocrit values. A higher level of significance was only obtained for pepsinogen.

food particlesize; blood; pigs; stomach lesions.

In a previous communication, Simonsson \& Björklund (1970) reported the effect of fine, medium and coarse ground barley in a mixed pig feed on hogs. Pigs fed the finest meal frequently developed parakeratotic or erosive lesions in the pars oesophagea of the stomach, the contents of which were more liquid and had a lower $\mathrm{pH}$ than those from pigs fed medium or coarse ground barley. The present investigation was performed to see if these changes could be detected in an altered blood composition, particularly in the blood pepsinogen level. 


\section{MATERIAL AND METHODS}

The pigs were purchased at a weight of about $20 \mathrm{~kg}$. They were fed a dry feed mixture of $90.6 \%$ barley, $7.0 \%$ defatted fishmeal, $1 \%$ ground lime, $0.4 \%$ sodium chloride and $1 \%$ vitamin and mineral premix mixed together by the Department of Animal Husbandry, Uppsala. The barley was ground in a hammer-mill to three different degrees of coarseness using 1.25, 2.25 and $5.25 \mathrm{~mm}$ screens. The pigs were divided randomly into three groups. Group 1 was fed the mixture containing fine, group 2 medium and group 3 coarse ground barley. The pigs were slaughtered weekly at a live weight as close to $90 \mathrm{~kg}$ as possible. Blood with and without the addition of heparin was collected the day before slaughter from 15 pigs fed fine, from 18 fed medium, and from 14 fed coarse ground grain. Heparinized blood samples are missing from one sampling occasion. Blood was obtained by puncture of the junction of vena jugularis and vena subclavia. The heparinized blood was analysed at the laboratory immediately. Serum was stored at $-26^{\circ} \mathrm{C}$ until analysis could be performed. Patho-morphological examination of the pigs was carried out as soon as possible after slaughter. For further details regarding the experimental conditions, see Simonsson \& Björklund (1970).

$\mathrm{H}$ e m o g lo bi n was determined as cyanmethemoglobin on an Autolab (L. Ljungberg \& Co, Stockholm, Sweden) automatic analyzer.

H e m a t o c rit was measured on an Adam's Autocrit (ClayAdams Inc., New York, N.Y., USA) after 3 min. centrifugation.

Erythrocytes and leucocytes were counted automatically with a Celloscope (L. Ljungberg \& Co, Stockholm, Sweden). Differential counts of leucocytes were done after the smears had been stained with May-Grünwald's and Giemsa's fluids. Two-hundred cells were counted.

Erythrocyte sedimentation rate (ESR) was performed according to Westergren on heparinized blood.

$\mathrm{Urea}-\mathrm{N}$ was determined with the urease technique using $\mathrm{Hy}$ land's commercial reagents (Hyland Laboratories, Los Angeles, Calif., USA).

C a l c i u m was determined with a Perkin-Elmer atomic absorptic spectrophotometer after dilution $1: 25$ with $0.1 \%$ lanthanum chloride.

Inorganic phosphate was determined according to Taussky \& Shorr (1953).

Total protein was determined as described by Weichselbaum (1946).

Electrophoretic separation was performed on an LKB (LKB, Solna, Sweden) apparatus using tris-buffer, pH 8.1 (Arons- 
son \& Grönvall 1957) and a running time of $16 \mathrm{hrs}$. on paper. Evaluation was done with a Beckman-Spinco Analytrol (Beckman Spinco Inc., Los Angeles, Calif., USA).

Alkaline phosphatase was determined according to King \& Armstrong (1934).

P e p s i n o g e n was determined according to Schotman \& Straver (1969), slightly modified. Only one fifth of the amount prescribed by these authors was used, and instead of filtering, the precipitate was separated by centrifugation.

$\mathrm{Stat}$ istical methods were used in accordance with Steel \& Torrie (1960).

\section{RESULTS AND DISCUSSION}

No statistically significant differences in growth rate and feed conversion could be detected among the groups. Of the $\mathbf{1 5}$ pigs on the finest meal all except one developed typical parakeratotic or erosive changes in the pars oesophagea of the stomach. The parakeratatic changes were judged as slight in one pig,

T a b l e 1. Hematological data (mean \pm standard deviation) from pigs of about $90 \mathrm{~kg}$ live weight fed on fine (group 1), medium (group 2) and coarse (group 3) ground dry grain.

\begin{tabular}{|c|c|c|c|c|c|c|}
\hline & \multirow[b]{2}{*}{ Group 1} & \multirow[b]{2}{*}{ Group 2} & \multirow[b]{2}{*}{ Group 3} & \multicolumn{3}{|c|}{ Student's t-test } \\
\hline & & & & $1-2$ & $2-3$ & $\overline{1-3}$ \\
\hline$\underset{n}{\operatorname{Hemoglobin}}(\mathrm{g} / 100 \mathrm{ml})$ & $\begin{array}{c}12.71 \pm 1.24 \\
11\end{array}$ & $\begin{array}{c}13.87 \pm 0.79 \\
13\end{array}$ & $\begin{array}{c}14.14 \pm 1.01 \\
12\end{array}$ & $2.77^{*}$ & 0.77 & $2.95^{* *}$ \\
\hline$\underset{\mathbf{n}}{\mathrm{Hematocrit}}(\%)$ & $\begin{array}{c}40.5 \pm 4.0 \\
8\end{array}$ & $\begin{array}{c}42.7 \pm 1.8 \\
11\end{array}$ & $\begin{array}{c}44.4 \pm 2.9 \\
10\end{array}$ & 1.61 & 1.65 & $2.40^{*}$ \\
\hline$\underset{n}{\text { Erythrocytes }}\left(10^{6} / \mu \mathrm{l}\right)$ & $\begin{array}{c}6.21 \pm 0.71 \\
12\end{array}$ & $\begin{array}{c}6.61 \pm 0.64 \\
12\end{array}$ & $\begin{array}{c}6.87 \pm 0.38 \\
11\end{array}$ & 1.25 & 1.17 & $2.46^{*}$ \\
\hline $\operatorname{MCHC}(\mathrm{g} / 100 \mathrm{ml})$ & 31.4 & 32.5 & 31.8 & & & \\
\hline $\mathrm{MCH}(\mathrm{pg})$ & 20.5 & 21.0 & 20.6 & & & \\
\hline MCV (mpl) & 65.2 & 64.6 & 64.6 & & & \\
\hline$\underset{n}{\operatorname{Leucocytes}}\left(10^{3} / \mu \mathrm{l}\right)$ & $\begin{array}{c}21.53 \pm 3.57 \\
12\end{array}$ & $\begin{array}{c}22.53 \pm 3.88 \\
12\end{array}$ & $\begin{array}{c}19.95 \pm 2.95 \\
11\end{array}$ & 0.60 & 1.77 & 1.17 \\
\hline Neurophil., band $\left(10^{3} / \mu \mathrm{l}\right)$ & $0.24 \pm 0.26$ & $0.28 \pm 0.38$ & $0.09 \pm 0.09$ & 0.30 & 1.56 & 1.76 \\
\hline,$\quad$, segment $(,)$, & $4.90 \pm 2.36$ & $6.96 \pm 2.96$ & $6.00 \pm 1.57$ & 1.80 & 0.91 & 1.24 \\
\hline Eosinophilic & $1.14 \pm 0.76$ & $1.02 \pm 0.72$ & $0.88 \pm 0.53$ & 0.39 & 0.50 & 0.91 \\
\hline Basophilic & $0.12 \pm 0.16$ & $0.23 \pm 0.27$ & $0.18 \pm 0.13$ & 1.12 & 0.28 & 0.95 \\
\hline Lymphocytes & $14.16 \pm 2.55$ & $13.63 \pm 2.95$ & $12.63 \pm 2.95$ & 0.73 & 0.89 & 1.53 \\
\hline Immature & $0.31 \pm 0.25$ & $0.26 \pm 0.26$ & $0.17 \pm 0.10$ & 0.51 & 0.97 & 1.69 \\
\hline$\underset{n}{\operatorname{ESR}}(\mathrm{mm} / \mathrm{hr})$. & $\begin{array}{c}19.0 \pm 16.5 \\
8\end{array}$ & $\begin{array}{c}9.5 \pm 7.6 \\
11\end{array}$ & $\begin{array}{c}13.4 \pm 13.9 \\
11\end{array}$ & 1.69 & 0.82 & 0.80 \\
\hline
\end{tabular}

$0.05>P>0.01$.

* $0.01>\mathrm{P}>0.001$. 
moderate in four, and severe in three. Four pigs had erosions of the epithelium (Figs. 1-5). In group 2 (medium grind) the corresponding number was seven out of 18 , of which four were judged as slight and three as moderate parakeratotic changes. No pathological alterations could be detected in the stomach of the pigs on coarse grain.

The blood chemical and hematological data given in Tables 1 and 2 for the groups 2 and 3 animals may serve as normal values for hogs of about $90 \mathrm{~kg}$ of live weight. The meal fed to the group 2 animals had a structure which is very similar to that used in most Swedish herds. The values obtained in all groups fall within the range for pigs obtained by several investi-

Table 2. Blood chemical data (mean \pm standard deviation) from pigs of about $90 \mathrm{~kg}$ body weight fed on fine (group 1), medium (group

2 ) and coarse (group 3) ground dry grain.

\begin{tabular}{|c|c|c|c|c|c|c|c|}
\hline & & & & & Stu & ent's $t-t$ & \\
\hline & & Group 1 & Group 2 & Group 3 & $1-2$ & $2-3$ & $1-3$ \\
\hline$\underset{n}{\text { Urea-N }} \underset{n}{(\mathrm{mg} / 100}$ & & $\begin{array}{c}20.6 \pm 4.4 \\
15\end{array}$ & $\begin{array}{c}19.3 \pm 4.9 \\
17\end{array}$ & $\begin{array}{c}15.9 \pm 3.2 \\
14\end{array}$ & 0.75 & $2.28^{\star}$ & $3.32^{* *}$ \\
\hline Calcium $\underset{n}{(\mathrm{mg} / 100}$ & ml) & $\begin{array}{c}10.53 \pm 0.76 \\
15\end{array}$ & $\begin{array}{c}10.44 \pm 0.38 \\
17\end{array}$ & $\begin{array}{c}10.67 \pm 0.72 \\
14\end{array}$ & 0.43 & 1.14 & 0.51 \\
\hline $\begin{array}{l}\text { Inorg. phosphoru } \\
(\mathrm{mg} / 100 \mathrm{ml})\end{array}$ & & $8.61 \pm 0.63$ & $8.73 \pm 1.02$ & $8.63 \pm 0.91$ & 0.39 & 0.27 & 0.10 \\
\hline $\begin{array}{c}\text { n } \\
\text { Phosphatase, alk } \\
\text { (KA units } / \mathrm{ml} \text { ) } \\
\text { n }\end{array}$ & & $\begin{array}{c}15.68 \pm 2.50 \\
15\end{array}$ & $\begin{array}{c}16.71 \pm 3.58 \\
17\end{array}$ & $\begin{array}{c}14.08 \pm 3.58 \\
13\end{array}$ & 0.86 & 1.86 & 1.39 \\
\hline$\underset{n}{\text { Total protein }}(\mathrm{g} /$ & $(0.0 \mathrm{ml})$ & $\begin{array}{c}8.05 \pm 1.37 \\
16\end{array}$ & $\begin{array}{c}7.50 \pm 0.42 \\
17\end{array}$ & $\begin{array}{c}7.79 \pm 0.53 \\
14\end{array}$ & 1.57 & 1.17 & 0.66 \\
\hline Albumin & $(,)$, & $3.75 \pm 1.00$ & $3.96 \pm 0.46$ & $4.07 \pm 0.52$ & 0.77 & 0.63 & 1.28 \\
\hline$\alpha_{1}$-globulin & $()$, & $0.34 \pm 0.08$ & $0.31 \pm 0.10$ & $0.34 \pm 0.13$ & 0.94 & 0.73 & 0.00 \\
\hline$\alpha_{2}$-globulin & $()$, & $0.67 \pm 0.18$ & $0.71 \pm 0.28$ & $0.68 \pm 0.18$ & 0.47 & 0.12 & 0.46 \\
\hline$\alpha_{3}$-globulin & $()$, & $0.45 \pm 0.12$ & $0.39 \pm 0.12$ & $0.45 \pm 0.16$ & 1.41 & 1.21 & 0.00 \\
\hline Total $\alpha$-globulin & $(,)$, & $1.46 \pm 0.25$ & $1.41 \pm 0.14$ & $1.48 \pm 0.11$ & 0.38 & 0.48 & 0.18 \\
\hline$\beta$-globulin & $(,)$, & $1.19 \pm 0.37$ & $0.98 \pm 0.24$ & $0.97 \pm 0.22$ & 1.94 & 0.12 & 1.94 \\
\hline$\gamma$-globulin & $()$, & $1.61 \pm 1.18$ & $1.17 \pm 0.34$ & $1.31 \pm 0.40$ & 1.45 & 1.05 & 1.08 \\
\hline $\begin{array}{l}\text { Alb./Glob. } \\
\text { Pepsinogen ( } \mu \mathrm{g}\end{array}$ & epsin & $1.00 \pm 0.41$ & $1.19 \pm 0.35$ & $1.15 \pm 0.31$ & 1.40 & 0.40 & 1.10 \\
\hline $\begin{array}{r}\text { equiv./ml) } \\
\mathrm{n}\end{array}$ & & $\begin{array}{c}4.01 \pm 0.73 \\
15\end{array}$ & $\begin{array}{c}4.73 \pm 0.89 \\
18\end{array}$ & $\begin{array}{c}4.30 \pm 1.41 \\
14\end{array}$ & $2.51^{*}$ & 1.87 & 0.11 \\
\hline
\end{tabular}

${ }^{*} 0.05>\mathrm{P}>0.01$.

** $0.01>\mathrm{P}>0.001$. 

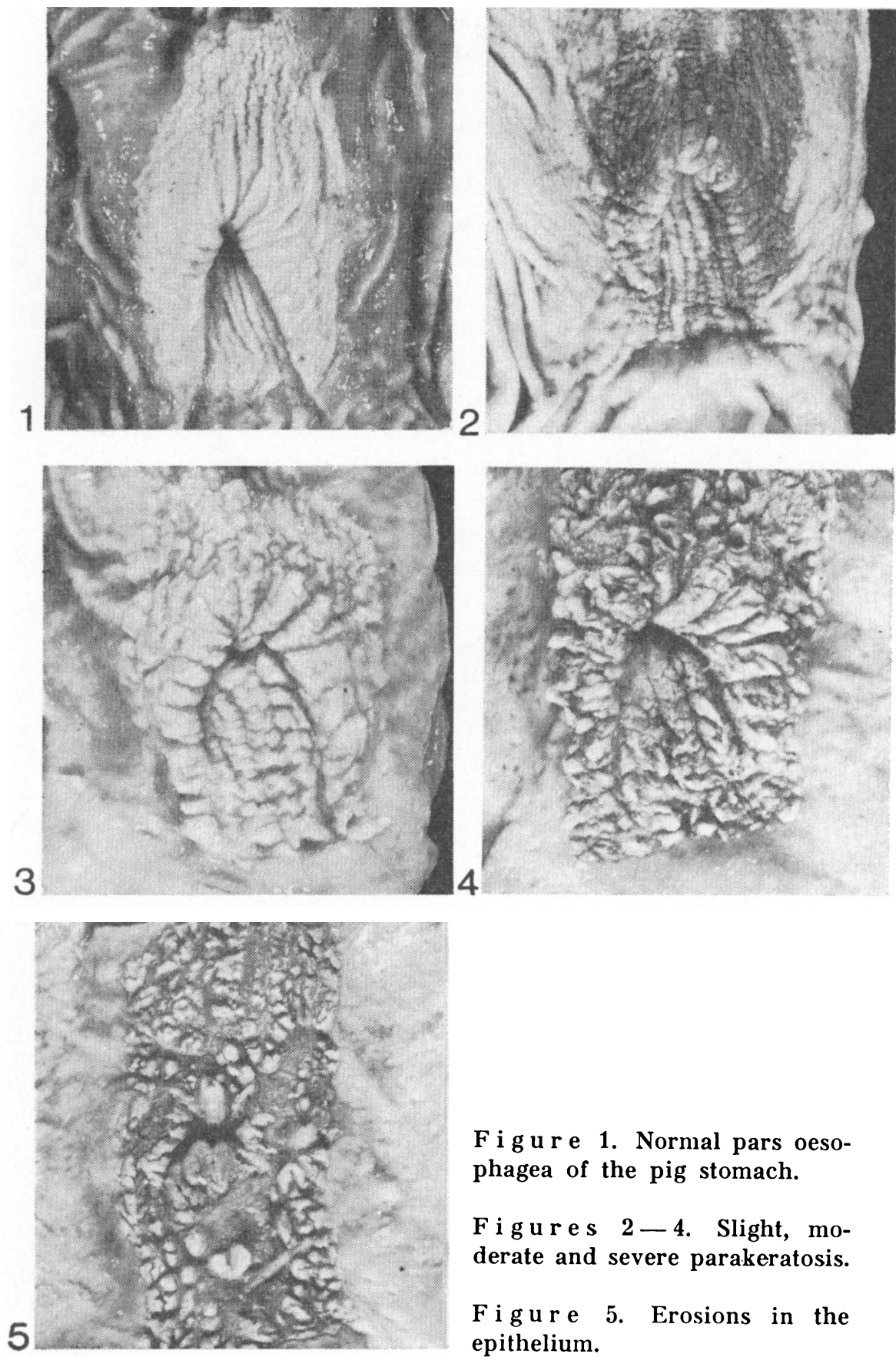

F i g u r e 1. Normal pars oesophagea of the pig stomach.

F i g u r e s 2-4. Slight, moderate and severe parakeratosis.

Figure 5. Erosions in the epithelium. 
gators, cited by Dunne (1964). There are, however, many limitations to a normal value. Different laboratories obtain varying results depending on analysis technique, and herd differences have been reported for several parameters in cattle (Payne et al. 1970).

Statistically significant or almost significant differences were obtained between the groups for hemoglobin, hematocrit, number of erythrocytes, urea-N and pepsinogen. A much wider range was observed in the $\gamma$-globulins of the group on fine grind than in the other two groups. The differences in proteins were, however, not significant.

To see whether the observed differences between the groups were related to the gastric pathological alterations or to the feed, a comparison was made between pigs with and without pathological changes (Table 3 ). There were still significant, though smaller, differences in the hemoglobin and hematocrit values. A higher level of significance was only obtained for pepsinogen.

T a ble 3. Statistical comparison between hematological and blood chemical values in pigs with and without macroscopical pathological alterations of the gastric mucosa (student's t-test).

\begin{tabular}{|c|c|c|c|c|c|c|c|}
\hline & \multicolumn{3}{|c|}{ With gastric alterations } & \multicolumn{4}{|c|}{ Without gastric alterations } \\
\hline & $\mathbf{n}$ & mean & $\mathbf{s}$ & $\mathbf{n}$ & mean & $\mathbf{s}$ & $t$ \\
\hline Hemoglobin $(\mathrm{g} / 1.00 \mathrm{ml})$ & 12 & 12.90 & 1.39 & 22 & 14.00 & 0.88 & $2.84^{* *}$ \\
\hline Hematocrit $(\%)$ & 9 & 40.4 & 3.6 & 19 & 42.9 & 1.9 & $2.30^{*}$ \\
\hline Erythrocytes $\left(10^{6} / \mu l\right)$ & 13 & 6.40 & 0.72 & 21 & 6.72 & 0.52 & 1.51 \\
\hline Leucocytes & 13 & 21.20 & 5.40 & 21 & 21.03 & 3.39 & 0.11 \\
\hline Neutrophil., band. (,) & 13 & 0.21 & 0.26 & 21 & 0.19 & 0.29 & 0.21 \\
\hline Neutrophil., segm. & 13 & 5.41 & 3.27 & 21 & 6.17 & 2.14 & 0.82 \\
\hline Eosinophilic & 13 & 1.17 & 0.91 & 21 & 0.85 & 0.74 & 1.37 \\
\hline Basophilic & 13 & 0.11 & 0.16 & 21 & 0.22 & 0.21 & 1.63 \\
\hline Lymphocytes & 13 & 13.11 & 4.68 & 21 & 13.25 & 2.62 & 0.11 \\
\hline Immature & 13 & 0.25 & 0.17 & 21 & 0.23 & 0.24 & 0.24 \\
\hline $\operatorname{ESR}(\mathrm{mm} / \mathrm{hr})$. & 9 & 16.7 & 15.9 & 20 & 11.5 & 11.8 & 1.00 \\
\hline$(\mathrm{mg} / 100 \mathrm{ml})$ & 17 & 20.3 & 4.64 & 28 & 17.7 & 4.5 & 1.85 \\
\hline Calcium & 17 & 10.47 & 0.66 & 28 & 10.55 & 0.58 & 0.42 \\
\hline Inorg. phosphorus (,,) & 17 & 8.72 & 0.81 & 25 & 8.56 & 0.86 & 0.61 \\
\hline Total protein $(\mathrm{g} / 100 \mathrm{ml})$ & 17 & 7.97 & 1.30 & 28 & 7.64 & 0.52 & 1.20 \\
\hline Albumin & 17 & 3.85 & 0.79 & 28 & 4.01 & 0.49 & 0.84 \\
\hline$\alpha$-globulins & 17 & 1.49 & 0.26 & 28 & 1.45 & 0.43 & 0.37 \\
\hline$\beta$-globulins & 17 & 1.14 & 0.37 & 28 & 0.99 & 0.24 & 1.62 \\
\hline
\end{tabular}

$* 0.05>P>0.01$.

* $0.01>\mathrm{P}>0.001$. 
The urea- $N$ of the plasma showed increased values in the groups fed fine and medium grind and this difference did not appear to depend on the development of pathological lesions.

The observed increase in urea- $\mathrm{N}$ may depend on a higher yield of protein resorption from the fine ground grain (cf. Cornelius \& Kaneko 1963), but could also depend on changes in the intestinal flora. Part of the urea synthesized by the liver is formed from ammonia of gastro-intestinal origin. Ammonia is produced by several enteric microorganisms, particularly those belonging to Clostridia and Klebsiella species (Summerskill 1970). The average number of $\mathrm{Cl}$. perfringens in the intestines of pigs on medium and fine ground barley was moderately and considerably elevated, respectively, in comparison with pigs on coarse grind (Månsson 1972). None of the observed urea-N values was pathologically increased (cf. Cornelius \& Kaneko).

The nature of the difference between the groups regarding the red blood cell picture is not understood. Perhaps the difference is due to differences in components of the gastric juice. The gastric secretions are considered to play an important role in promoting inorganic iron absorption (Jacobs 1970).

No inflammatory changes could be detected on macroscopical post-mortem examination of the internal organs of any of the pigs. The wide range in $\gamma$-globulin observed in the pigs on fine ground meal may therefore be related to deviation in the intestinal flora (compare above) rather than infections.

Blood calcium and phosphorus did not appear to be affected at all by the grind of the feed. This does not agree with alterations in the Ca: $\mathrm{P}$ ratios reported by Milic et al. (1969) in a similar feeding experiment.

The lower serum pepsinogen concentration observed in pigs with gastric changes is surprising, since Reimann et al. (1968) found higher concentration of pepsinogen in the gastric juice of pigs with lesions in pars oesophagea. However, according to Edwards et al. (1960) neither plasma nor urinary pepsinogen levels can be correlated directly to the amount and concentration in the gastric juice. They consider that these assays are instead related to the number of chief cells in the gastric mucosa. Analysis of the gastric mucosa may clarify this problem. 


\section{CONCLUSION}

Pigs fed on fine ground barley often developed stomach lesions and developed changes in the blood composition in comparison with pigs on coarse ground grain. The concentration of serum pepsinogen was lower in animals with lesions than in those with normal stomachs.

\section{REFERENCE}

Aronsson, T.\&W. A. Grönvall: Improved separation of serum proteins in the paper electrophoresis - a new electrophoresis buffer. Scand. J. clin. Lab. Invest. 1957, 9, 338-341.

Cornelius, C. T. E. \& J. J. Kaneko: Clinical Biochemistry of Domestic Animals. Acad. Press, New York and London 1963, p. 155.

Dunne, H. W.: Disease in Swine. Iowa State Univ. Press, Ames, Iowa 1964.

Edwards, K., R. P. Jepson \& K. F. Wood: Value of plasma pepsinogen estimation. Brit. med. J. I, 1960, 30-32.

Jacobs, A.: Digestive factors in iron absorption. In Progress in Gastroenterology. Vol. II. Grune and Stratton, New York and London 1970, 221-235.

King, E. J. \& A. R. A. Armstrong: A convenient method for determining serum and bile alkaline phosphatase activity. Canad. med. Ass. J. 1934, 31, 376-381.

Milić, D., A. Loncarević, Z. Stokić, C. Stankovic, D. Levajlic, M. Milinovic \& A. Pavlovic: Some observations on the incidence and etiology of oesophagogastric ulcer in swine. Veterinaria (Sarajevo) 1969, 18, 313--327.

Månsson, I. Personal communication 1972.

Payne, J. M., S. M. Dew, M. J. Manston \& M. Faulks: The use of a metabolic profile test in dairy herds. Vet. Rec. 1970, 87, 150157.

Reimann, E. M., C. V. Maxwell, T. Kowalczyk, N. J. Benevenga, R. H. Grummer \& W. G. Hoekstra: Effect of fineness of grind of corn on gastric lesions and contents of swine. J. Animal Sci. 1968, 27, 992-999.

Schotman, A. J. H. \& A. J. M. Straver: De bepalung van serum pepsinogen bij klinisch gezonde runderen. (The determination of serum pepsinogen in clinically healthy cows). T. Diergeneesk. $1969,94,653-659$.

Simonsson, A.\& N. E. Björklund: Differently processed barley for the growing pigs. Growth rate, food conversion efficiency, digestibility, carcass quality and development of oesophagogastric lesions. The Sovjet-Swedish Symposium at Ultuna, September 15-17, 1970.

Steel, R. G. D. \& J. H. Torrie: Principles and Procedures of Statistics. McGraw-Hill Book Inc., N. Y., Toronto and London 1960. 
Summerskill, W. H. J.: Ammonia metabolism in the gastrointestinal tract. In Progress in Gastroenterology. Vol. II. Grune and Stratton, New York and London 1970, 276-287.

Taussky, H. H. \& E. Shorr: A microcolorimetric method for the determination of inorganic phosphorus. J. biol. Chem. 1953, 202, $675-685$.

Weichselbaum, T. E.: An accurate and rapid method for the determination of proteins in small amounts of blood serum and plasma. Amer. J. clin. Path., Tech. Sect. 1946, 10, 40-49.

\section{SAMMANFATTNING}

Hematologiska och blodkemiska undersökningar av svin, som torrutfodrats med finmalet, medelgrovt och grovt spannmål.

Dagen före start togs blodprov från grisar som utfodrats med finmalet, något grövre eller grovmalet spannmål (korn). Vid slakten konstaterades att av femton grisar, som erhållit finmalet foder (grupp 1), uppvisade fjorton stycken parakeratos eller erosioner i magsäckens pars oesophagea. Hos djur som utfodrats med något grövre foder var motsvarande siffror sju av aderton. De djur som fått grovt foder var utan anmärkning. Blodet undersöktes i enlighet med tabell 1-3. Signifikanta eller nästan signifikanta skillnader mellan grupperna erhölls för hämoglobin, hämatokrit, antal erytrocyter, urea-kväve och pepsinogen. $\gamma$-globulinet visade större variation bland djuren som utfodrades med finmalet foder än hos övriga djur. Men skillnaderna i proteiner var ej signifikanta.

För att se om iakttagna skillnader mellan grupperna var relaterade till magsäcksförändringarna eller till foderstrukturen jämfördes djur med och djur utan magsäcksförändringar. Skillnaderna var fortfarande signifikanta (ehuru mindre) vad gäller hämoglobin och hämatokritvärdena. En högre grad av signifikans erhölls för pepsinogen.

(Received March 13, 1972).

Reprints may be requested from: N.-E. Björklund, National Veterinary Institute, S-104 05 Stockholm 50, Sweden. 